\title{
Lexiconul Staicu în raport cu cele din familia Berînda: ortografie și alcătuire ${ }^{\dagger}$
}

\author{
Ion-Mihai Felea ${ }^{\star}$ \\ Facultatea de Litere, Universitatea „Alexandru Ioan Cuza”, Bd. Carol I 11, 700506 Iași, România
}

\section{Despre articol}

Istoric:

Primit 12 mai 2021

Acceptat 5 iulie 2021

Publicat 18 august 2021

Cuvinte-cheie:

lexicologie istorică

analiză comparată

\begin{abstract}
Rezumat
În secolul al XVII-lea apar primele manuscrise cu dicționare slavo-române, iar șase dintre acestea au ajuns pînă în zilele noastre în formă aproape intactă. Punctul lor de plecare a fost Lexiconul lui Pamvo Berînda (1627), la care au fost adăugate mai multe liste de cuvinte în unele manuscrise. Aceste manuscrise au fost studiate pînă în prezent în special din perspectivă lexicală.

Studiul de faţă și-a propus să descrie modalităţile de alcătuire a lexicoanelor, să observe variațiile ortografice importante și să devină un instrument în plus pentru stabilirea rețelei de filiații din care au rezultat lexicoanele românești. Observațiile sînt făcute asupra intrărilor de la primele trei slove din lexicoanele amintite. Avînd la dispoziție toate lexicoanele în format digital, am identificat propagarea mai multor erori în rîndul antigrafelor românești, am evidențiat mai multe fapte de grafie și am comparat listele suplimentare.

Datele arată că manuscrisele românești conservă în grad diferit ortografia din Lexiconul lui Berînda şi listele suplimentare. Variațiile sugerează existența a cel puțin unui protograf între sursă și lexicoanele românești. Aplicată la întreg conținutul manuscrisului, investigarea acestor variații ar putea contribui la identificarea manuscrisului care este cel mai apropiat de redacția inițială.
\end{abstract}

\section{Introducere}

Prin „familia Berînda” înțelegem Lexiconul slavo-rutean al lui Pamvo Berînda [= BER], tipărit prima dată în 1627 la Kiev, și un grup de lexicoane slavo-române din secolul al XVII-lea, care au avut ca punct de pornire tipăritura ruteană. Acestea sînt: Lexiconul Staicu (ms.rom. 312 BAR, în continuare Lex.Sta.), lexiconul din ms. rom. 1348 BAR scris de Mihai Logofătul (= Lex.1348), lexiconul din ms. rom. 3473 BAR copiat de un anume Mihaiu (= Lex.3473), Lexiconul de la Petersburg(OP Q.XVI.5 BNR, numit în continuare Lex.Pet.), Lexiconul lui Mardarie din ms. rom. 450 BAR (= Lex.Mard.) și Lexiconul de la Moscova (F.188, Op.1. nr.1383, RGADA, în continuare Lex.Mosc.). Manuscrisele românești au beneficiat de o atenție inegală, în special din cauza faptului că două dintre ele se afă în Rusia. Departe de a fi exhaustiv, voi aminti doar că Lex.Mard. a fost editat de Crețu (1900) într-un volum încă util, iar Lex.Mosc. a fost studiat parțial de Ciobanu (1914). Lex.Sta. și autorul său au făcut obiectul preocupării lui Strungaru (1973) și Gînsac \& Ungureanu (2019). Perspective de ansamblu au oferit Strungaru (1966), Аевичкин \& Сухачев (2015) şi Gînsac \& Ungureanu (2018). Întrucît lucrările menţionate s-au concentrat preponderent pe componenta lexicală a dicționarelor, am considerat oportună abordarea filiației și din unghiul mai puțin exploatat al ortografiei. Mai multe manuscrise au devenit accesibile prin procedee de digitalizare, avem mai multe informații despre normele ortografice din epocă, iar fonturi precum cele create în cadrul proiectului Ponomar $^{1}$ ne dau posibilitatea să explicăm diferențe care altădată au fost trecute cu vederea. De asemenea,

${ }^{\dagger}$ Această lucrare a fost finanțată printr-un grant al Ministerului Cercetării, Inovării și Digitalizării din România, CNCS/CCCDI - UEFISCDI, proiect nr. PN III-P1.1-TE-2019-0517, în cadrul programului PNCD III.

*Adresă de corespondență: imfelea@gmail.com.

${ }^{1}$ Despre misiunea și realizările proiectului Ponomar putem citi aici: ponomar.net. 
am urmărit să cataloghez acele divergențe care nu se pot explica doar prin gradul de libertate pe care și-l luau cărturarii cînd copiau dintr-un manuscris în altul.

Pînă la apariția ediției comparative integrale pe care ne-am propus-o în cadrul proiectului eRomLex (vezi scriptadacoromanica.ro), studiul de față a valorificat materialul primelor 3 litere: I, E și G. Toate cuvintele slavone au fost transcrise ținînd cont de toate nuanțele ortografice atunci cînd fidelitatea a fost necesară argumentării. Traducerile din manuscrisele românești au fost marcate cu italic.

\section{Compoziţia}

Lexiconul Staicu, aflat pe filele $41^{\mathrm{v}}-216^{\mathrm{v}}$ ale ms.rom. 312 BAR, este un efort colaborativ al mai multor persoane. Conține cca 6000 de nume proprii, substantive comune slavone și, într-o proporție mai mică, grecești și ebraice ordonate după alfabetul slavon. Spre final include alte două liste de cuvinte, considerabil mai scurte decît lexiconul de bază. Acestora le urmează cîteva liste lexicale tematice, de exemplu traducerea numelor de animale din Lev, 11. Lexiconul de bază reprezintă o adaptare a BER, cu cîteva deosebiri importante. Față de tipăritura ruteană, numele proprii sînt trecute imediat după cele comune, nu separat. A doua diferență notabilă este că după materialul din BER fiecare literă conține măcar o foaie de conținut independent de lexiconul rutean. Aceste intrări suplimentare aparţin aceleiași mîini și reprezintă în proporție covîrșitoare cuvinte în slavonă, rusă sau ruteană. În continuare vom folosi pentru definițiile cu echivalent în BER convenția Staicu ${ }_{1}$, iar pe cele copiate dintr-o sursă neidentificată le vom considera scrise de $\mathrm{Staicu}_{2}$, fără a pierde din vedere că este vorba de una și aceeași persoană. Conținutul preluat din BER de Staicu 1 variază, însă pentru unele litere este preluat aproape integral. Cuvintele scrise de Staicu 2 sînt ordonate aproximativ alfabetic, în sensul că par preluate în grupuri de cîte 3-5 cuvinte aranjate alfabetic, între care se intercalează uneori cuvinte ce nu par la locul lor. Acest haos aparent s-ar putea explica prin relație cu alte tipuri de lexicoane timpurii. Este posibil ca lexicoanele noastre să fi completat listele lexicale din Berînda cu intrări din unul sau mai multe proto-dicționare slavone. Pentru a justifica ipoteza, putem lua în calcul mai multe informații. Această ipoteză este susținută de informațiile despre structura lexicoanelor medievale, care nu aveau întotdeauna aranjamentul pe care îl așteptăm astăzi de la un dicționar (Ковтун, 1989, p. 23). O metodă comună de ordonare a intrărilor era în capitole care grupau cuvinte după inițială și a doua vocală din cuvînt (Карпов, 1877, p. 137); alteori definițiile erau separate pe categorii tematice: luni ale anului, părți ale corpului, nume proprii, plante etc. Primul principiu ar putea

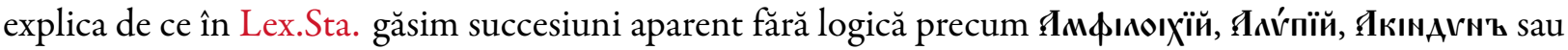
Прте́миъ, Яве́

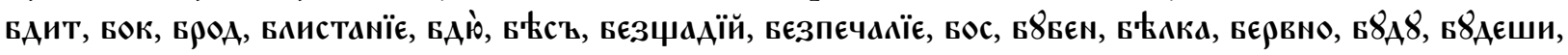
в8 Dacă admitem pe влистанїє drept completare de paradigmă a luі влћскъ și refacem formele istorice ale

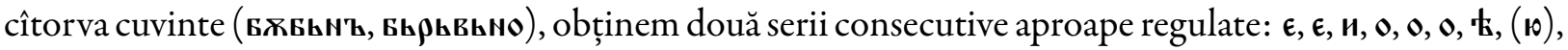

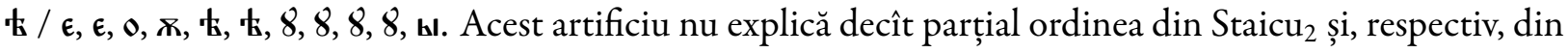
restul manuscriselor românești, dar, dacă ipoteza este adevărată, rezultă că intrările $S_{t a i c u}$ au fost copiate din cel puțin un lexicon slavon timpuriu. Definițiile copiate de Staicu 2 nu par a fi grupate tematic, însă unele definiții apar acolo unde ne-am aștepta să le găsim în dicționare tematice. De exemplu la final de Б găsim succesiunea вонифантий, ворис, вори, 'ъ. Categoriile numelor proprii apar la final de literă și în alte dicționare slavone (Карпов, 1877, p. 136; pentru clasificarea lexicoanelor rusești, a se vedea Ковтун, 1989, p. 9). O ordine similară, pseudo-alfabetică, găsim, de exemplu, în ms. nr. 1649 din colecția Pogodin a Bibliotecii Naționale a Rusiei, un lexicon de mici dimensiuni datînd de la jumătatea secolului al XVI-lea ${ }^{2}$. Consider, deci, că e posibil ca traducerea din $\mathrm{Staicu}_{2}$ să se făcut din slavonă după un manuscris apropiat ca formă și conținut de cele care au apărut din secolul al XV-lea și în spațiul rus. Pentru exemplificare, mă voi referi la intrarea вори,o,' (tradusă o iarbă ascuțită la miros în Lex.Mosc., Lex.1348, și o iarbă iute la miros în

\footnotetext{
${ }^{2}$ Textul digitalizat poate fi consultat aici: oldlexicons.ru.
} 
Lex.Sta.), raportînd-o la Lexiconul lui Serghei, un manuscris copiat în jurul anului 1650 la mănăstirea rusească Solovieț ${ }^{3}$ și descris de $\Lambda$ евичкин \& Сухачев (2015, p. 440) drept cel mai cuprinzător lexicon rusesc medieval. Lexiconul lui Serghei are structura pe care am descris-o mai sus, iar la secțiunea Eo găsim intrarea

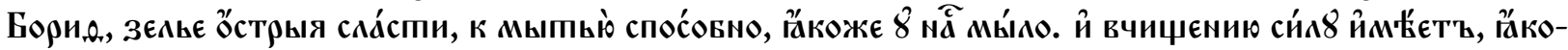

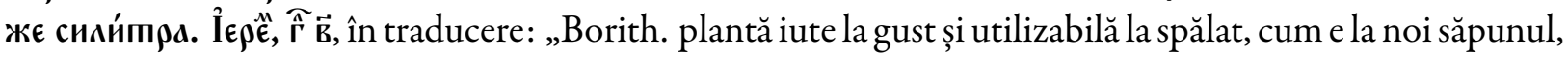
și putere de curăţare are precum silitra. Ierem 2". Deducem că două dintre lexicoanele noastre au ales primul sens al lui острый, cel de 'ascuțit', în timp ce Staicu a optat pentru sensul celălalt, mai potrivit, de 'iute', fie pentru că avea textul slavon în față, fie pentru că a înțeles sursa erorii. Борn, os și alte cîteva intrări adiacente lipsesc din Lex.1348, însă acesta conține în continuare cca. 30 de definiții pe care alte manuscrise nu le înregistrează. Nu înregistrează intrarea nici Lex.Mard. sau Lex.Pet.

Sursa definițiilor copiate de $S_{t a i c u}$ nu are cum să fie Lexiconul lui Serghei, desigur, însă e relevant faptul că majoritatea intrărilor de la $\mathbf{E}$ pot fi găsite, în altă ordine, și în manuscrisul rus. E posibil ca ele să fi făcut parte dintr-un fond comun de definiții care au migrat dintr-un lexicon slavon în altul, uneori simplificîndu-se ca în manuscrisele românești, alteori căpătînd caracter enciclopedic, ca în dicționarul de la Solovieț. Nu este obligatoriu ca aceste liste suplimentare de la Staicu să provină dintr-o singură sursă. În Lex.Mard. litera $\mathbf{6}$ se termină cu intrările Бодєць, Бодєнєць și Бодєж. În lexiconul său Staicu 2 trage linie

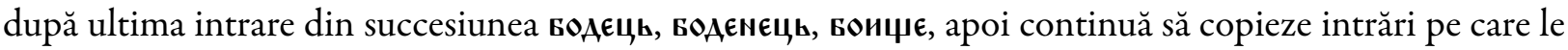
regăsim și în celelalte lexicoane românești. Nu putem fi siguri că Staicu ${ }_{2}$ folosește două liste diferite, dar e plauzibil că linia semnalează finalul unei liste comune cu Lex.Mard.

\section{Scribii lexiconului Staicu}

Pe lîngă textul grămăticului, lexiconul a suportat intervenţii din partea mai multor cititori. Unele mîini au lăsat sporadic definiții sau observații, în timp ce altele au modificat considerabil conținutul dicționarului. Este dificil de spus cîte persoane au contribuit la conținutul manuscrisului, întrucît forma scrisului este afectată de mai mulți factori: instrumentul de scris, tipul de intervenție - notă marginală, finală sau refacere a manuscrisului, limba în care scrie.

\subsection{Mîna Lupaşcu}

Primele două pagini ale literei A, între Язъ și Ягрипнї̈, au fost scrise de aceeași mînă. Conform unei însemnări de pe pagina $41^{\mathrm{v}}$ din 1 mai 1758, manuscrisul a fost în posesia unui dascăl Lupaşcu. Deși ortografia este mult mai îngrijită, recunoaștem în ea mîna care va suplini lexiconul cu numeroase intrări. Pagina $41^{\mathrm{v}}$ a fost lăsată goală pe jumătate și a fost completată ulterior cu niște note etimologice de o mînă de proveniență neclară. Definițiile 1-9, pînă la ЯরчБd, se găsesc și în BER. Celelalte, pînă la Ягрипнї̊, au fost probabil copiate dintr-un alt manuscris, legat într-o măsură mai mică de BER. În sprijinul acestei afirmații vin: aranjarea alfabetică aproximativă, selecția deosebit de rarefiată dacă s-ar explica prin BER,

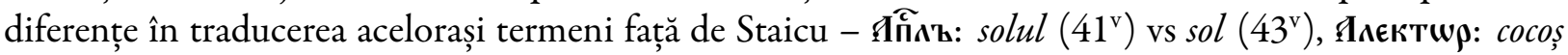

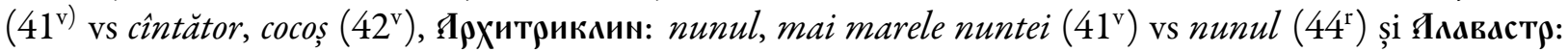
sticlă, marmură vs șip de sticlă sau de marmură $\left(42^{\mathrm{v}}\right)$, intrarea Ягавиє, care nu există în BER, lexiconul rutean înregistrînd doar două intrări đrakłz. Este probabil că đгaвïe și đraвł sînt sfinți diferiți, deoarece în Lex.Mosc., Lex.Pet. și Lex.Sta. există minimum o intrare concordantă cu Berînda pentru Яrak'z, iar traducerile diferă (Irakïє: batjocură față de Irak's: luminat).

Lupașcu a lăsat încercări lexicografice sub forma unor mici grupuri de cuvinte și pe paginile de dinaintea lexiconului. Multe au corespondent în BER, însă unele sînt evident rutenisme fără vreo legătură cu slavona sau cu limbile sud-slave: к8^л: glonț $\left(31^{\mathrm{r}}\right)$, рєєстрй или сал: rînduială, -ire. Primul este atestat cu sensul militar, conform GSBM (s.v. kyлs), încă din secolul al XVI-lea, în timp ce al doilea este atestat în rusă la 1665 (Vasmer, s.v. peecmp). Ambele exemple au fost împrumutate în rusă din poloneză, direct sau

\footnotetext{
${ }^{3}$ Pe site-ul RNB găsim o excelentă copie digitală sub cota OP Con. 18/18 (nlr.ru).
} 
printr-un intermediar rutean. $\mathrm{MDA}_{2}$ îl atestă pe glonț în Letopisețul lui Costin, dar ar fi interesant de văzut dacă există ocurențe anterioare deceniului 1670.

Tot Lupașcu a notat o intrare la finalul literei A și, la finalul literei B, mai multe, din care merită să examinăm cîteva:

- Бєзмезано: în zadar, în har. Atestat în texte rusești din secolul al XVIII-lea, deși familia lexicală este reprezentată și în texte sud-slave încă din secolul al X-lea, cf. SJs, s.v. вєзмьзАьникъ și MIKL, S.v. вєзмьзАнно.

- Боты: cizme. După Vasmer, împrumutat de rusă din polonă în jurul secolului al XV-lea, unde la rîndul lui a fost împrumutat din franceză. Neatestat în bulgară, unde, de exemplu, ботуш este considerat împrumut din română (DEB, s.v. бomyzu).

- Б8тылка: sticlă. De asemenea împrumutat în rusă din franceză direct sau printr-un intermediar polon ori rutean.

- Вык: taur. Cf. ru./ bel. бъı, dar ucr./bg./sr-cr. бик. OCS выкъ.

- Бараваn: alăută. În DEB cuvîntul este considerat împrumut din rusă, deși nu se specifică perioada împrumutului sau prima atestare.

- Багаж: odor din casă. La Vasmer (s.v. бazaж) prima atestare este din 1706. Termenul a fost împrumutat din franceză pe filieră poloneză sau germană. Suscită interes traducerea românească, mai ales coroborată cu sensul 'bagaj, calabalîc' pentru pilotă în zona Moldovei $\left(\mathrm{MDA}_{2}\right.$, s.v. pilotă).

- Башмаки или ов8ви: рарисі. După Vasmer (s.v. башмак), primul cuvînt este împrumutat dintr-o limbă turanică, de ex. ciagatai.

E aproape sigur că mîinii Lupașcu îi aparțin o bună parte din intervențiile constante lăsate pe marginile corpului de text Staicu. Comparînd scrisul de la început de A, final de B și notele marginale: выхованєц, питомєц: fecior de suflet $\left(58^{\mathrm{v}}\right)^{4}$, вєкша: veveriță cîinele ș.a, ies în evidență cîteva trăsături grafice. Majuscula $\mathbf{Q}$ cu serifă pronunţată, m cu trei picioare și serifă la capătul superior al piciorului din stînga, E-ul, \$-ul cu corp triunghiular, \$-ul, 8-ul ușor înclinat, ц-ul, $\kappa$-ul cu linii sinuoase, $\rho$-ul suprascris al cărui picior este înclinat la aproximativ 45 de grade față de orizontală, toate aceste litere sînt scrise de aceeași mînă sau, cel puțin, de oameni cu deprinderi grafice extrem de apropiate. Unele cuvinte sînt răspîndite pe întreg arealul slav, de pildă вłнo sau вравиıঞ. Primul exista atît în rusa pre-modernă (SDI, s.v. въннo), cît și în bulgară, astăzi dialectal și învechit. Al doilea este

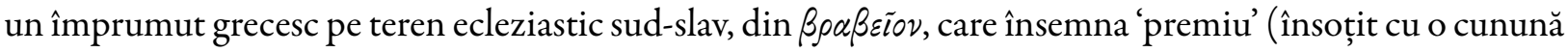
de palmier, cf. palmares) în slavonă și în rusa pre-modernă ajunge să însemne 'ramură de palmier' sau orice substitut convenabil pentru sărbătoarea Floriilor (sRs18, s.v. вравиe). Alte glose marginale sînt legate exclusiv de spațiul slav nord-răsăritean. În expresia ßоскй regională ucraineană (sum, s.v. ckiмлитu), unde vocalele se închid adesea la [i]. Ar putea fi o glosă biblică extrasă din $E x, 11,7$.

\subsection{Mîna anфo}

La finalul literei A găsim două intrări, una notată de Lupașcu一ПрХивах: писмо Храникищах: cămări de scrisori-și una de o mînă necunoscută-anфo: acum încă-, intrare care lipsește în BER și care notează un termen dificil din a doua carte a Regilor. În textul ebraic (BHs, $2 R g, 2,14)$ găsim îmbinarea 'a $\bar{p} h \bar{u}$, pe care SEPT o lasă netradusă, redîndu-o prin $\alpha \varphi \varphi \omega$. Această formulare a pus probleme și traducătorilor slavi. Unele texte slave îl transcriu $\mathbf{a} \Pi \phi o-$ BIS $^{6}$, de exemplu, sau $\mathbf{a} \phi \$ o$, OST și PAN îl evită complet, Biblia de la Moscova (o reeditare din 1663 a OST) îl omite, dar notează aфò pe margine. SEPT.FRANK îl transcrie $\alpha \pi \varphi \dot{\omega}$, iar VULG îl traduce prin „etiam nunc”, adică „chiar acum”.

Această mînă anфo notează uneori la final de literă definiții care prezintă polnoglasie și uneori completează definițiile lui Staicu [врашно: bucate, mîncare (Staicu), făină (апфо)].

${ }^{4}$ Cf. ucr. вихованець și bel. выхаванещ.

${ }^{5}$ Cuvînt din slava de est, neînregistrat în bulgară.

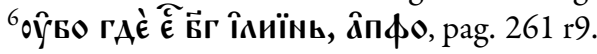




\subsection{Mî̀ni de proveniență neclară}

Alte completări care par de proveniență ruteană sînt викиница și вр8ткка. Primul exemplu este de fapt o rescriere a unei intrări Staicu, aflată un rînd mai sus. Intrarea modifică tk-ul în $\mathbf{n}$ și reformulează ușor traducerea. Intervenția nu îmbogățește lexiconul, însă închiderea th indică un vorbitor familiarizat cu limbile slave vorbite la nord de Moldova: rusn. бiльıŭ, ucr. бínuй, ceh. bilý. La sud de Dunăre, în schimb, izoglosa k-ului a împărțit vorbitorii în două grupuri mari, la est unde se pronunță un $a$ iotat (bg. вяа), și la vest, unde sunetul se pronunță $e^{7}$. În al doilea caz, lîngă traducerea Lex.Sta.: țeavie sau duda,

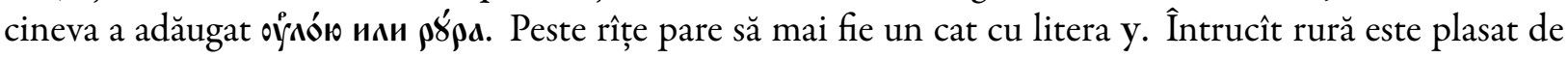
DLRLC în graiurile nordice (Moldova sau Bucovina), iar etimonul este unul rutean, intrat prin poloneză din germanul Rohr = 'țeavă' (WSJP, s.v. rura), putem presupune că mîna care a lăsat glosa aparținea unui cărturar din nordul țării. Lexicoanele Lex.Mosc., Lex.Pet., Lex.3473 și Lex.1348 traduc identic prin țeavie de aramă, fără explicații suplimentare, iar Lex.Mard. notează eronat îndemînă, influențat fiind probabil de intrarea anterioară вр8чєємїє.

Pe prima pagină de la B, cineva lasă notița Баџан'ъ, pe bulgărie zice tată. Nu este clar dacă autorul e vorbitor de bulgară sau, dimpotrivă, un vorbitor de rusă sau ruteană care notează o formă necunoscută lui. În favoarea celei de-a doua ipoteze ar pleda ucraineanul modern бaumau 'harbuzărie'. În manuscrisele românești sînt multe exemple de perechi omofone, atît în secțiunile traduse după BER, cît și în celelalte. Poate că cel care notează Бащанł și-a propus să opună cuvîntul bulgar unuia rutean pe care îl cunoștea deja.

În Lex.Pet., la finalul literei $\mathbf{l}$ sînt trei intrări care nu se regăsesc în alte dicționare, una dintre ele fiind вєприни: agrişu. Probabil scribul cunoștea deja cuvîntul вєприна 'carne de mistreț' sau 'femela porcului mistreț', comun mai multor limbi slave (ucr., sb. etc. cf. вєпрь: porcu, gliganu în Lex.Pet.) și a dorit să adauge un regionalism specific Ucrainei de sud-vest, zonă adiacentă arealului nord-românesc (sUM, s.v. 2. веприна).

Scenariul cel mai plauzibil este acela în care primele pagini din lexiconul originar Staicu s-au pierdut sau nu fuseseră copiate deloc, iar Lupaşcu a suplinit aceste lipsuri la o dată ulterioară, extrăgînd selectiv mai multe definiții din minimum două surse și completînd dicționarul cu un număr de definiții la final sau la început de literă. În general completările sale vin primele, imediat după mîna Staicu, dar în unele cazuri, după cum pare a fi cel de la finalul slovei $\Gamma$, între două intervenții ale sale au mai fost adăugate intrări. În

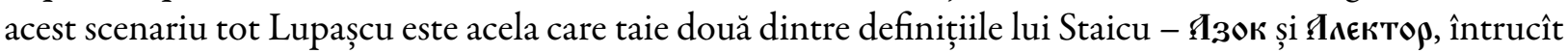
ele fuseseră deja notate și traduse în reconstrucția sa.

În fine, pe manuscrisul 312 și-au lăsat amprenta grafică într-o epocă mai tîrzie cel puțin alți doi posesori. Unul dintre ei, Jean de Talmatzy ${ }^{8}$, intervine rar cu echivalări în latină și franceză. La pag. $50^{r}$, intrarea вразАна: holdă este încadrată într-un chenar ce conține traduceri în greacă și latină, franceză (champ laboure), rusă (земля обработанаs) și română (boldă, pămînt lucrat), la care o altă mînă a adăugat un al doilea chenar cu traducerile holdă sau dealniță.

\subsection{Mîna Staicu}

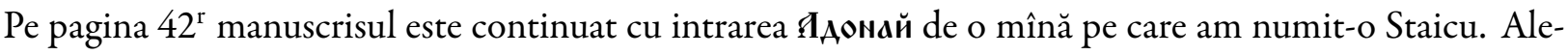
gerea arată că acceptăm demonstrația lui Strungaru (1966), care i-a atribuit grămăticului de la Tîrgoviște paternitatea manuscrisului. Lexiconul datorează peste $95 \%$ din conținut acestei mîini Staicu. După ce termină de prelucrat materialul lexical din BER, Staicu 2 adaugă alte 66 de intrări în care putem distinge vreo 5 grupuri ordonate oarecum alfabetic. Completările Staicu 2 nu se regăsesc în Lex.Pet., Lex.1348 sau Lex.Mosc. (în Lex.3473 litera A nu s-a păstrat, iar Lex.Mard. întrerupe litera subit). Cu două excepții,

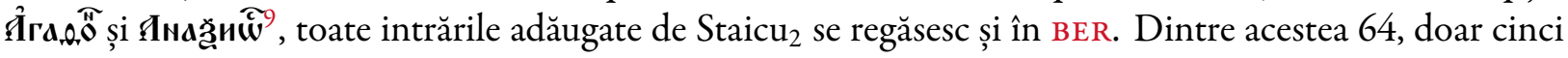

\footnotetext{
${ }^{7}$ Cf. mc. бes, sb-cr. bèo, bijêl, bêl, dar dialectal și бùo.

${ }^{8}$ Jean de Talmatzy a lăsat la 20 martie 1797 o însemnare de apartenență pe fila $41^{\mathrm{r}}$.

${ }^{9}$ Ambele intrări sînt prezente în diverse lexicoane slavone și slavo-ruse: oldlexicons.ru/node/2355 și oldlexicons.ru/node/1038.
} 
sînt intrări noi, restul sînt dubluri ale unor intrări notate deja anterior, unele dintre ele repetîndu-se chiar de două ori. Putem emite și ipoteza că avem în față maculatorul unui student care încearcă să învețe o listă de nume, traducîndu-le în reprize, pînă și le însușește satisfăcător.

\section{Ortografia}

În general, ortografia conținutului slavon din manuscrisele românești nu este identică cu cea din BER. Chiar admițînd ipoteza unui protograf românesc deosebit de fidel față de BER, redacțiile succesive ale antigrafelor n-au făcut decît să se îndepărteze succesiv de acesta, aplicînd ortografia slavonă de redacție românească. În Lex.Sta., spre deosebire de BER, combinația spirit - accent ascuţit (") este trecută consecvent pe vocala inițială, consoanele în poziții alăturate codă - atac la granița dintre silabe sînt separate relativ consecvent de mîna Staicu prin paieric ( ${ }^{4}$ ) sau chiar prin ier (IMbMa) —o face și BER, sporadic însă—, uneori consoanele sînt dublate: Lex.Sta. Я̆̌малй vs BER Ямаликъ, în unele cazuri literele grecești sînt adaptate fonetic:

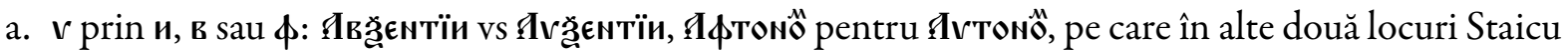
îl transcrisese totuși cu v. Întrucît $S_{\text {taicu }}$ scrie Ivтоном imediat după Яв că scribul era obișnuit ori să scrie cu в în loc de v, ori să-l pronunțe așa.

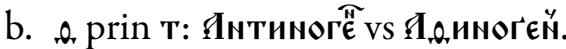

c. X prin ф: Яิмфикохїй vs Яӑфинофїє.

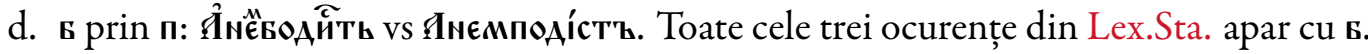

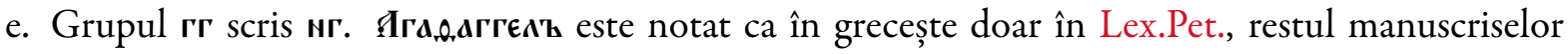
analizate operează înlocuirea.

f. Grupurile lichidă-ier $(\mathbf{\rho} \mathbf{b} / \mathbf{A} \mathbf{b} / \mathbf{\rho b} / \mathbf{A b})$ sînt adesea notate așa cum bănuim că se pronunțau în epocă, adică cu vocalizarea ierului înainte de lichidă în funcție de etimon: ăr, er, or, ăl, el, ol etc.

În orice caz, substituții de felul celor evidențiate mai sus deschid posibilitatea ca acesta să fi copiat lexiconul după dictare.

BER folosește uneori ortografia cu vocalizare acolo unde cuvintul are corespondent în vernaculară

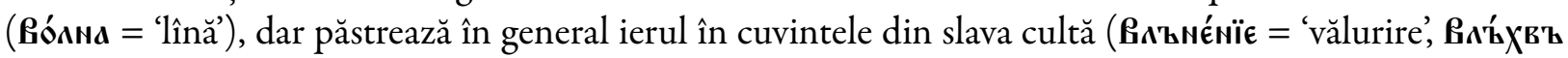
= 'vrăjitor'). Mai mult, păstrează ortografia tradițională chiar și acolo unde este evident că pronunța cu

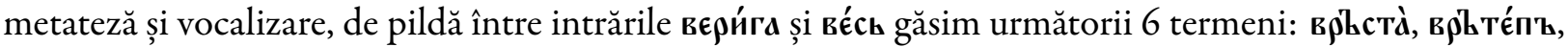

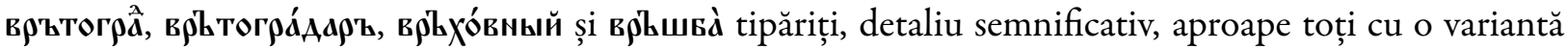
supradimensionată de ier mare. BER nu face o regulă din a semnala vocalizarea prin ier mare în versiune înaltă, însă tendința există, în special în combinațiile lichidă-ier, și este posibil ca ea să reflecte ortografia surselor din care și-a extras Pamvo Berînda definițiile. Cu o singură excepție, lexicoanele noastre nu par să utilizeze un ier înalt, deși par să facă uneori diferența între ier vocalizat și ier final sau între ier mare și ier mic, în special acolo unde distincția este exemplificată prin perechi minimale în BER (Lex.Pet.: вón'ъ: afară, вóнь: într-însu; Lex.3473: ве́çв: sat, вéck: de tot). Peste tot această succesiune de 6 definiții apare exact ca în BER între вєри́г și вéch. Intrările sînt transcrise în Lex.Pet., Lex.1348, Lex.3473 și Lex.Mosc. tot cu ier, fie ca în Ber, fie cu metateză (Lex.Mosc., Lex.3473: върттппъ; Lex.3473: въьрховный), fie

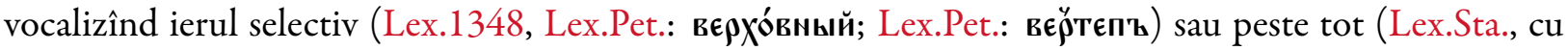
excepția primei intrări - връшва).

Excepția de care pomeneam mai sus este Lex.Mard. Dacă în restul surselor, ca în toate lucrările manuscrise, este dificil de făcut un inventar complet al setului de caractere, în Lex.Mard. este limpede că scribul cunoștea diferența dintre ierurile mari înalte și normale, pe de o parte, și ierurile mici, pe de alta. Ierul mare înalt este folosit inclusiv în grupul de cuvinte pe care tocmai l-am analizat și din care omite doar intrarea врҺшва̀, deși nu-l folosește exclusiv în poziție tare (cf. вҺса̂̀никь) și uneori îi conferă o altă dimensiune ortografică decît în BER (cf. в'́́nь: afară, вíhns: într-însul).

Manuscrisele românești încorporează în grade diferite semnele suprascrise din BER. Un caz interesant este cel al kamorei $\left({ }^{\wedge}\right)$, care a marcat multă vreme la slavi accentul sau palatalizarea. În prima jumătate a 
secolului al XVII-lea gramaticile lui Smotrițki propun introducerea ei în antistih, adică recondiționarea ei într-un simbol care diferențiază omofonia morfologică. Noua normă a fost preluată rapid în textele kievene tipărite (Kusmaul', 2017). Berînda o folosește, de pildă, pentru a diferenția ß̊á́в’z ('văduv', masc.

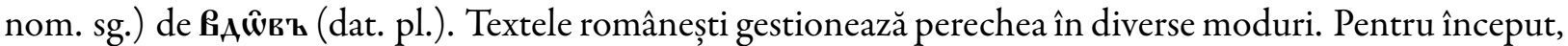
Lex.Mosc., Lex.Sta. și Lex.3473 au o intrare în plus - RAwra (fem. sg.). Lex.Pet. și Lex.1348 păstrează

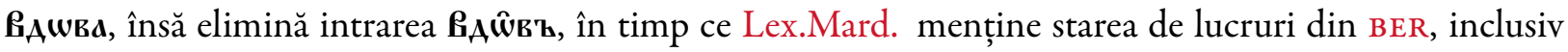
diacriticele. Dintre toate intrările, doar despre ßас̂িвa din Lex.Mosc. se poate spune aproape fără dubiu că

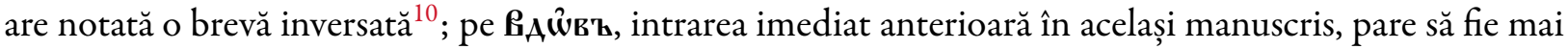
degrabă un spirit lin. Tot spirit lin pare să suprascrie pe omega și copistul Lex.1348, Lex.Sta. și Lex. 1348 notează un accent ascuțit, în timp ce Lex.Pet. urmează o convenție ortografică ușor diferită, notînd în general accent ascuțit pe ó și chendima (dublu accent grav sau dublu accent ascuțit) pe ẅ. Din utilizare nu putem spune cu siguranță că românii au înțeles pe deplin utilizarea brevei inversate în BER, în orice caz au încercat, cel puțin în primă instanță, să o transcrie, iar unde nu au mai înțeles-o, s-au rezumat la a transcrie conform propriilor norme.

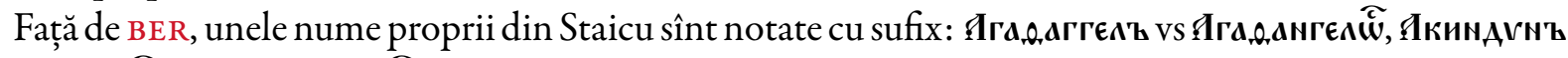

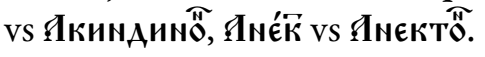

Numele proprii sînt adesea românizate în Lex.Sta., înlocuindu-se mai exact terminațiile ïa, ra prin $\boldsymbol{n} \epsilon$ și

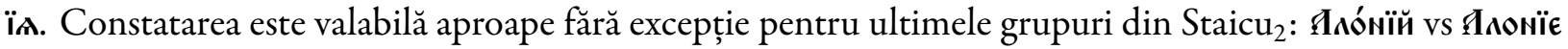
ș.a. Alte lexicoane românești sînt mai conservatoare din acest punct de vedere.

Altă eroare care s-ar putea explica prin BER este grafia Пвєnw, unde, la un moment dat în istoria transmiterii textului, un copist român a confundat ierul mic cu un $\mathbf{o}$, iar de aici la $\mathbf{w}$ n-a fost decît un pas.

Toate manuscrisele au locuri în care ordinea din BER nu este respectată exact. Cazurile nu sînt frecvente și se explică prin neglijență.

O serie de erori amuzante din Lex.Pet. ne deschide o fereastră suplimentară spre procesul de lucru din scriptoriile medievale. Fiecare intrare slavonă începe cu chinovar, însă în unele locuri inițiala lipsește, iar în altele aceasta se află înaintea unui cuvînt românesc aflat la început de rînd:

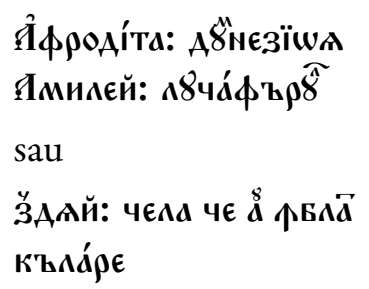

În primul exemplu, intrarea Afrodita avea explicația dumnezioaia milei, Luceafărul. Copistul a adăugat din greșeală un A cu chinovar rîndului imediat următor, transformînd o intrare în două. În exemplul al doilea a fost evident omisă slova Ĭ. Copistul a scris mai întîi intrările fără inițială, apoi a revenit cu chinovar și, din neatenție, a comis erori de felul celor de mai sus. Curios este însă faptul că după milei a notat două puncte, ca și cum luceafărul ar fi în fapt explicaţia termenului Amilei, deci sînt șanse reale ca eroare să nu-i fi aparținut, ci să fi fost preluată din alt manuscris.

\section{Redactare}

Intrarea Я(в)Aи́й, tradusă cărunteațe în Lex.Pet. și Lex.Mosc., ilustrează modul în care s-au raportat la

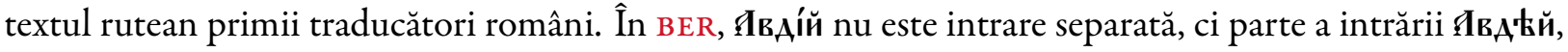
șef al bucătarilor regelui Ahab. Berînda precizează că đв_íí este profet sărbătorit pe 19 noiembrie și ne

\footnotetext{
${ }^{10}$ În slavonă acest semn se numește камора. Mulțumesc pe această cale lui Alexandr Andreev și părintelui Nikita Simmons pentru amabilitate și clarificări legate de utilizarea brevei inversate.
} 
Ion-Mihai Felea

oferă descrierea acestuia în ПодА'Łнник ${ }^{11}$ : „cărunt, cu barbă nu prea mare, rotundă, părul vîlvoi, haina de culoarea ocrului, verzuie la poale, ținînd în mînă un sul”. Întrucît numele propriu se află la început de rînd, traducătorul român a luat primul cuvînt din citat - G'kA'b și l-a tradus nu foarte exact prin „căruntețe”. Lipsindu-le originalul, celelalte lexicoane au preluat această intrare fără modificări, Lex.Pet. omițînd chiar slova в, deoarece copiază, probabil, un manuscris de felul Lex.Mosc., unde в-ul este suprascris într-un mod care-l înghesuie în intrarea anterioară. Această manieră de a traduce cel mult unul dintre sinonimele rutene, pe acela care pare mai familiar traducătorului român, se observă de mai multe ori în cuprinsul lexicoanelor românești. O altă confuzie găsim la intrarea IzMoAéocra, unde manuscrisele românești confundă ruteanul кази́тель 'cel care strică' cu казмитель 'cel care chinuie' și traduc în consecință: muncitor, căznitor. Strategia alternează cu o alta, în care se ignoră partea ruteană și se traduce, uneori literal, intrarea slavonă.

Lexicograful rutean explică intrarea Я̆̌́v́sd astfel: „Bolnav sau ce tinde spre pierdere. Bun și drept. Fapt. 18. Iul 14, ian. 20, feb. 13. Lat: аквí^A, vultur." Staicu ${ }_{1}$, alături de restul lexicoanelor românești, traduce Якима prin bolnav, iar din trimiterea latină face intrare aparte. Staicu 2 copiază de trei ori termenul,

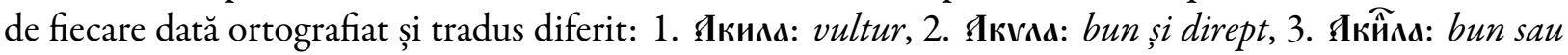
prost, ultimele 2 definiții preluînd cealaltă jumătate a explicației din BER.

La Icńpł Lex.Sta., Lex.Pet., Lex.Mosc. și Lex.1348 (cu observaţia că ultimul manuscris transcrie Ipŕcı) combină într-una singură cele două intrări din BER, despre care cărturarul rutean ne spune că se scriu diferit în ebraică, una cu samekh şi alta cu shin.

$\mathrm{Nu}$ rare sînt cazurile în care manuscrisele românești au cuvinte suplimentare față de BER. Acestea reprezintă într-o măsură covîrșitoare desfășurări de paradigmă ale unor termeni din BER, diverse forme verbale, adjective derivate din substantive sau invers. Tipăritura ruteană conține uneori note gramaticale legate de aspectul verbelor, diateză, gen, originea etimologică, explicaţii ortografice, trimiteri bibliografice. Uneori, aceste note sînt preluate şi în textele românești; alteori, copistul român inserează din proprie

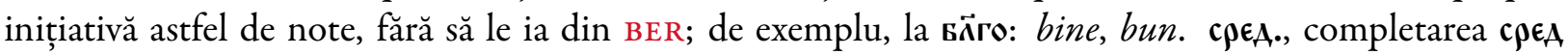
(= slav. 'neutru') nu are corespondent în BER.

\section{Studiu de caz}

Să luăm o succesiune de 12 definiții tipărite de BER pe coloana $355^{12}$ :

\begin{tabular}{|c|c|c|c|c|c|}
\hline BER & Lex.Mosc. & Lex.Pet. & Lex.Sta. & Lex.1348 & Lex.Mard. \\
\hline Ясcáрїй & Яccápïй: banul & ศ̆ccápïй: banul & $\begin{array}{l}\text { Я̊čcapïн: banul, } \\
\text { mangăr }\end{array}$ & - & Fileariu, mangăr \\
\hline Ясcápïй & - & - & - & - & - \\
\hline 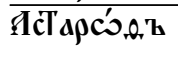 & - & - & - & - & $\begin{array}{l}\text { [se termină } \\
\text { litera] }\end{array}$ \\
\hline Ясmápmъ & - & - & - & - & \\
\hline Яспи́́pïn̆ & 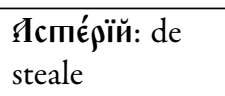 & 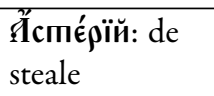 & $\begin{array}{l}\text { Ясппрїи: de } \\
\text { steale }\end{array}$ & 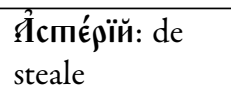 & \\
\hline- & - & - & - & $\begin{array}{l}\text { đ̆čcápïn̆: banul, } \\
\text { fost-au și niște } \\
\text { bani de lut și } \\
\text { piiale la Rîm de } \\
\text { s-au chiemat } \\
\text { assari. }\end{array}$ & \\
\hline
\end{tabular}

\begin{tabular}{|c|c|c|c|c|}
\hline Ясmроло́ґıа & $\begin{array}{l}\text { Ястроло́гїа: de } \\
\text { steale cetire }\end{array}$ & $\begin{array}{l}\text { Я̆cmроло́гїа: de } \\
\text { steale cetire }\end{array}$ & $\begin{array}{l}\text { Яcmponórïa: } \\
\text { cetitor de steale }\end{array}$ & 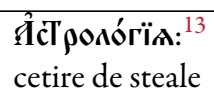 \\
\hline
\end{tabular}

\footnotetext{
${ }^{11}$ Manual slavon de iconografie, corespunde parțial ghidului bizantin Herminia.

${ }^{12}$ BER și-a numerotat coloanele, cîte două pe pagină, așa că pentru localizare am folosit chiar numerotarea lui. Să ținem cont însă că tipărirea s-a făcut în cîteva reprize, cu revizuiri, așa că exemplarele existente astăzi nu sînt perfect identice.

${ }^{13}$ În Lex.1348 intrarea aceasta și următoarea sînt scrise cu ligatură T $\rho$. Din păcate, redarea ligaturilor pe calculator rămîne problematică. Unele fonturi le includ în Private Area, soluție acceptabilă, dar departe de perfecțiune. Fontul Ponomar permite
} 


\begin{tabular}{|c|c|c|c|c|}
\hline Ястроло́ґъ & $\begin{array}{l}\text { Ястроло́г'ъ: } \\
\text { cetitor de steale }\end{array}$ & - & - & $\begin{array}{l}\text { ЯึcТроно́г̌: } \\
\text { cetitoriu de steale }\end{array}$ \\
\hline - & $\begin{array}{l}\text { Яcсарї̈̆й banul, } \\
\text { fost-au și niște } \\
\text { bani de lut și de } \\
\text { piiale la Rîm de } \\
\text { s-au chemat } \\
\text { assarii }\end{array}$ & $\begin{array}{l}\text { П̌ccápïn̆: banul, } \\
\text { fost-au și niște } \\
\text { bani de lut și de } \\
\text { piiale la Rîm de } \\
\text { s-au chemat } \\
\text { assarii }\end{array}$ & $\begin{array}{l}\text { Øैčcapïn̆: banii, } \\
\text { fost-au și niște } \\
\text { bani de lut și de } \\
\text { piale la Rim de } \\
\text { s-au chiemat } \\
\text { assarii }\end{array}$ & - \\
\hline Ястрономі́a & - & - & - & - \\
\hline Яси́гкрї & $\begin{array}{l}\text { Яcvґкрі: mai } \\
\text { slăvit }\end{array}$ & 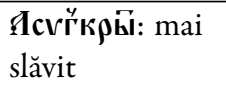 & $\begin{array}{l}\text { Îcírкрй: eresetut } \\
\text { mai slăvit }\end{array}$ & $\begin{array}{l}\text { Ясигкрй: mai } \\
\text { slăvit }\end{array}$ \\
\hline ITî̀̀ & - & - & - & - \\
\hline ЯТта́киа & ØТmásł: crescut & $\begin{array}{l}\text { ЯТmász: } \\
\text { crescutu }\end{array}$ & $\begin{array}{l}\text { Ân̆manz: } \\
\text { crescut }\end{array}$ & ด̆ \\
\hline ЯТта́къ & $\begin{array}{l}\text { IТта́кма: } \\
\text { stricătoriul }\end{array}$ & $\begin{array}{l}\text { ПТта́к̌на: } \\
\text { stricătoriul }\end{array}$ & $\begin{array}{l}\text { Яl̆manïa: } \\
\text { stricătoriul }\end{array}$ & $\begin{array}{l}\text { Ân̆máñna: } \\
\text { stricătoriul }\end{array}$ \\
\hline
\end{tabular}

Cîteva lucruri devin evidente din tabel. În primul rînd, Lex.Sta. este cu siguranță o copie la cel puțin a doua generaţie românească. Tendința autorului este de a micşora numărul de definiții, însă de a multiplica explicațiile. Mîna Staicu 1 omite intrarea đcmposó́r'z, dar îi copiază din greșeală explicația aferentă la in-

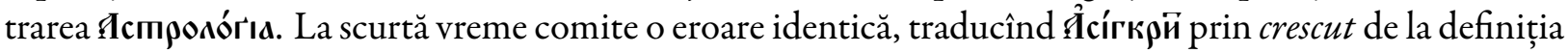
următoare și corectînd imediat printr-o tăietură.

Al doilea lucru evident este că Lex.Mard. reprezintă rodul unei redacții distincte de celelalte trei.

$\mathrm{Al}$ treilea lucru clar este că Lex.Mosc. nu poate fi copia niciunuia dintre manuscrisele analizate. Posibilitatea unei filiaţii din Lex.1348 este minimalizată de exemple furnizate în altă parte.

Pînă la o analiză în profunzime a întregului material lexicografic, mă voi mărgini să remarc că schema propusă în Gînsac \& Ungureanu (2018) pare să corespundă mai bine realităţii decît filiaţiile avansate anterior în literatura de specialitate. Cercetătoarele ieșene au teoretizat existența a cel puțin unui intermediar între BER și grupul Lex.Pet., Lex.Sta. și Lex.3473. Datele prezentate mai sus creionează profilul unui manuscris foarte apropiat de Lex.Mosc.. Pe lîngă faptul că Lex.Mosc. are intrări care lipsesc în celelalte manuscrise, iar traducerile celorlalți martori lexicografici converg spre cele din Lex.Mosc., ortografia intrărilor analizate este identică cu cea din BER, căruia îi imită adesea și variantele de slovă. Lex.Mosc. nu folosește spirite pe vocala iniţială ca Lex.Sta., Lex.Pet. și Lex.1348, nu înlocuiește pe T prin m sau pe v prin и/I și nu inserează un paieric între consoane vecine ca Lex.Sta. și Lex.1348 (ocazional și Lex.Pet.), nici nu suprascrie litera finală, nici nu înlocuiește a prin A ca Lex.1348. Mai mult, pare să fie singurul care încearcă

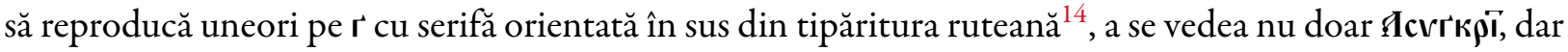
și ЯрXıсrнarúr, unde apar ambele variante, deosebirea dintre ele fiind manifestă.

Două detalii din tabel s-ar opune totuși identificării presupusului intermediar cu Lex.Mosc. Primul

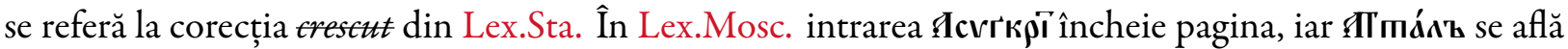
în capul paginii următoare, deci lui Staicu n-ar fi putut să-i fugă ochii la definiția următoare. Admit, însă, că se poate la fel de bine imagina și o explicație în care tocmai trecerea de la o pagină la alta îi dă copistului ritmul peste cap și-l face să greșească. De asemenea, nu este clar dacă đTmáxнa din BER a fost transcrisă cu и sau cu N de copistul Lex.Mosc. Sînt aproape sigur că optează pentru varianta greșită. Din fericire, în cazul celorlalte 3 manuscrise lucrurile sînt cît se poate de clare. Lex.Pet. și Lex.1348 transcriu greșit cu N și

afișarea cîtorva ligaturi prin inserția unui jointer de lăţime zero (ZWJ: U+200D) între următoarele perechi de slove: ₹ $x$ af, însă doar în $\mathrm{ATEX}_{\mathrm{E}}$ și LibreOffice Writer, nu și în Microsoft Word. În așteptarea unor soluții mai bune, am inserat un ZWJ între tverdi și rîțe.

${ }^{14}$ Precizez că acest tip de glagol a fost folosit în incunabule slavone tipărite în Uniunea statală polono-lituaniană pentru a indica pe g în cuvinte de origine greacă și nu făcea parte din norma ortografică a slavonei din Țările Române. Așadar, apariția lui în spațiul românesc nu poate decît să indice contactul cu un original rutean. Pentru detalii a se vedea vezi Andreev et al. (2015, p. 11). În BER caracterul este de înălțimea unei majuscule, înălțimea fiind și criteriul după care l-am identificat în Lex.Mosc. Din păcate, fontul folosit în articol nu reflectă această diferență. 
acest lucru este confirmat de prezența paiericului după $\Lambda$. În acest caz, cu atît mai importantă ni se relevă intrarea din Lex.Sta., copiată corect și univoc prin ï, întrucît ne împinge să căutăm un alt protograf. În același timp, nu putem exclude nici întîmplarea, nici o corecție informată. Dincolo de neglijența uneori exasperantă, Staicu pare un bun cunoscător de slavonă și un cărturar competent.

Este și cazul numelui propriu

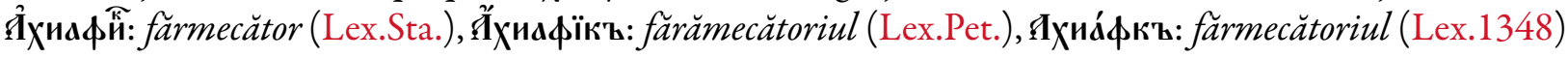
și Яхиафькъ: fărmecătoriul (Lex.Mosc.). Confuzia pleacă chiar de la Berînda, care dorește să îmbogățească intrarea Achsaph: Veneficus [etc] din STEPH ${ }^{15}$ cu echivalentul din canonul slavon. În versiunile

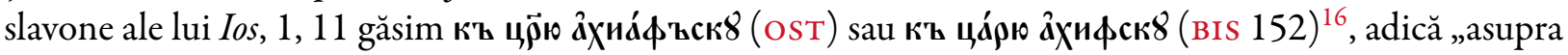
regelui ahifit/ Ahiafului”, dar Berînda interpretează sufixul adjectival de localizare geografică -cк drept parte a numelui (cf. SEPT.FRANK: $\alpha \chi \iota \alpha \varphi$ ), iar copiștii români sînt puşi în fața unui grup consonantic pe care nu-l pot digera. Prin prisma celor discutate mai sus, desfăşurarea evenimentelor se prezintă simplu. Lex.Mosc. vede în Ber un $\mathbf{b}$ în loc de c, Lex.1348 suprascrie ierul, în timp ce Lex.Pet. și Lex.Sta. îl vocalizează la ï/n.

\section{Concluzii}

Lexiconul Berînda a reprezentat o realizare intelectuală remarcabilă și, în cazul concret al ms. rom. BAR 312, a stat la baza unui text folosit timp de peste un secol de mai mulți utilizatori care l-au îmbunătăţit permanent. Numărul mare de lexicoane românești apărute într-un timp relativ scurt ilustrează impactul formidabil pe care l-a avut. Ele ar putea fi rodul unei sinteze între tipăritura ruteană și un dicționar slavon de dimensiuni mai mici. Acest dicționar ipotetic avea o structură diferită de dicționarele noastre și, ca multe alte proto-dicționare similare din spațiul cultural slavon, a rezultat probabil dintr-o colecție de glose. În fața noastră stă o provocare dublă, una de a desena un profil cît mai exact al acestui proto-dicționar ipotetic, iar cealaltă de a reface rețeaua de filiații a lexicoanelor românești din familia Berînda. Pentru prima sarcină ar trebui să investigăm cu mai multă atenție lexicoanele slavone din interiorul și din afara țării, în speranța că vom avea norocul să descoperim un manuscris care să explice cît mai bine listele lexicale din manuscrisele românești. Pentru cea de-a doua am putea să ne întrebăm nu doar cît de înrudite sînt lexicoanele noastre între ele, ci și cît de mult se apropie de tipăritura lui Berînda. Dincolo de traducerile termenilor, merită explorate și alte abordări care să vizeze aspectul textelor, compartimentarea listelor, interpretarea, corectarea și perpetuarea erorilor. În afară de Lex.Mard., care conține o redacție ușor diferită și este cel mai vechi, Lex.Sta. este datat de majoritatea estimărilor cu cel puțin cîțiva ani mai devreme decît restul lexicoanelor. Celelalte manuscriselor conțin însă numeroase elemente ale unei redacții mai vechi și prezintă o apropiere mai mare de BER. Lex.Mosc. este plasat în studiile anterioare undeva la cumpăna dintre secolele al XVII-lea și al XVIII-lea, dar ortografia, inventarul de termeni și dispunerea listelor care îl compun indică o redacție foarte apropiată de prima traducere românească. Deși prudența recomandă ca numărul manuscriselor ipotetice să cît mai mic, variația mare de liste, traduceri și erori face ca ipoteza unui singur protograf să nu explice satisfăcător filiațiile lexicoanelor românești de secol XVII.

\section{Bibliografie}

\section{A. Izvoare}

BER = Pamvo Berînda, Аексіконъ славеноршсскій и именъ Тлъкованїє, Kiev, 1627, [online]. BHS = Biblia Hebraica Stuttgartiensia, Deutsche Bibelgesellschaft, 1997, [online].

вIS = Ветхого Завета Книги: Моисеевь пять, Иисуса Навина, Судей, Руфь и четьце Царства. Palie-manuscris copiată la

Bistrița, păstrată azi la Biblioteca de Stat a Rusiei, F. 256, nr. 29, anul 1537, [online].

Lex.1348 = Lexiconul din ms. rom. 1348 BAR $\left(1-84^{\mathrm{v}}\right)$; fără foaia de titlu.

Lex.3473 = Lexiconul din ms. rom. 3473 BAR (1-369 $)$; fără pagină de titlu.

\footnotetext{
${ }^{15}$ Lucrare din care Berînda împrumută o mare parte din materialul numelor proprii.

${ }^{16}$ lib-fond.ru.
} 


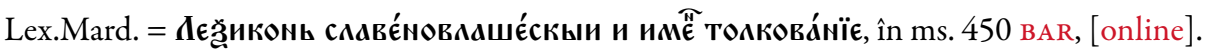

Lex.Mosc. = Lexicon slavo-român, RGADA, fondul 188, nr. 1380, fără foaia de titlu.

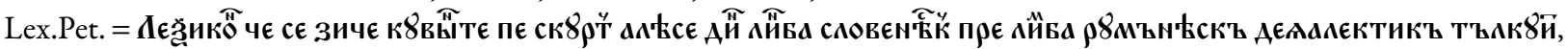
BNR, OP Q.XVI.5.

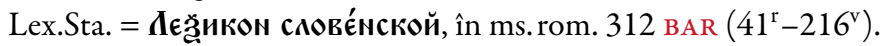

OST = ОСТРОЗБКА БІБАІЯ [Biblia de la Ostrog]. Ediție cu transcriere, facsimle și traducere paralelă ucraineană îngrijită de arhimandritul Rafail (Роман Торконяк), Liov, 2006.

PAN $=$ Vechiul Testament în traducerea lui Daniil Andrei Panoneanu, ms. rom. 4389 BAR, [online].

SEPT $=$ Septuaginta. Id est vetus Testamentum Grace iuxta LXX Interpretes, A. Rahlfs (ed.), Wurttembergische Bibelstalt, 1971, [online].

SEPT.FRANK = TH $\Theta E I A \Sigma \Gamma P A \Theta H \Sigma$. Divine scripture, nempe veteris ac novi testamenti, Frankfurt, 1597.

STEPH = Robert Stephanus, Hebrea, Chaldaa, Graca et Latina nomina virorum, mulierum, populorum, idolorum, urbium,

fluuiorum, montium, caterorúmque locorum qua in Bibliis leguntur, restituta, cum Latina interpretatione, 1537.

vULG = Biblia Sacra Vulgate editionis, Sixti V Pontificis Maximi jussu recognita et edita, Typographus Vaticanus, 1598, [online].

\section{B. Dicționare}

DEB = Български етимологичен речник [Dicționarul etimologic bulgar], ed. ВА. И. Георгиев et al., 9 vol., Sofia, 1971-prezent. DLRLC = Dicționarul limbii române literare contemporane (sub direcția prof. univ. Dimitrie Macrea și acad. Emil Petrovici).

Volumul I: $A-C, 1955$; volumul al II-lea: $D-L, 1956$; volumul al III-lea: $M-R, 1957$; volumul al IV-lea: $S-Z, 1958$,

Editura Academiei, [București].

GSBM = Гістарычны слоўнік беларускай мовы [Dicționarul istoric al limbii belaruse], Minsk, 1986, [online].

$\mathrm{MDA}_{2}=$ Micul Dicționar Academic, ed. a II-a, red. M. Sala, I. Dănăilă, Editura Univers Enciclopedic, București, 2010.

MIKL = Miklosich, Fr. (1862-1865). Lexicon Palaslovenico-graco-latinum, Guilelmus Braumueller, Vindobonæ, [online].

SDI = Словарь древнерусского языка $(X I-X I V$ вв. $)$ [Dicționarul limbii ruse vechi (sec. XI-XIV)], Academia de Științe a URSS,

Institutul limbii ruse, Editura Русский язык, Moscova, 1988.

sJs = Elektronický slovnik jazyk staroslovènského [Dicționar electronic al limbii slave vechi], dicționar digital realizat în cadrul proiectului Gorazd, aflat sub patronajul Institutului de Studii Slavone al Academiei de Științe a Republicii Cehe, [online].

SRs 18 = Словарь русского язықа XVIII века [Dicţionarul limbii ruse a sec. al XVIII-lea], Academia de Științe a URSS, Institutul limbii ruse, Editura Наука, Sankt Petersburg, 1984-1991.

sum = Словник української мови [Dicționarul limbii ucrainene], 11 vol., Editura Наукова аумка, Kiev, 1970-1980.

Vasmer = Vasmer, M. (2004). Этимологи́ческий словаррь ри́сского языюка [Dicționarul etimologic al limbii ruse], ed. О. Н. Трубачёв, АСТ.

wsJp = Wielki stownik języka polskiego [Marele dicționar al limbii poloneze], ed. P. Żmigrodzki, dicționar online aflat sub patronajul Institutului limbii poloneze pe lîngă Academia de Științe a Poloniei, 2012-prezent.

\section{Literatură secundară}

Andreev, A., Shardt, Y. \& Simmons, N. (2015). Church Slavonic Typography in Unicode, Unicode Technical Note \#41, [online].

Ciobanu, Șt. (1914). Славяно-румьинский словарь библиотеки Московскаго Общества Истории и Аревностей по 240 [Dicționarul slavo-român din biblioteca Societății Mocovite de Istorie și Antichitate], în „Русский фимологический вестникъ”, LXXI (1), p. 75-88.

Crețu, G. (ed.) (1900). Mardarie Cozianul. Lexicon slavo-românesc și tîlcuirea numelor din 1649, Edițiunea Academiei Române, Institutul de Arte Grafice „Carol Göbl”, Bucuresci.

Gînsac, A-M. \& Ungureanu, M. (2018). La lexicographie slavonne-roumaine au XVIIe siècle, în „Zeitschrift für romanische Philologie", 134 (3), p. 845-876.

Gînsac, A-M. \& Ungureanu, M. (2019). Lexiconul de la Moscova în raport cu celelalte lexicoane slavo-române din secolul al XVII-lea, în „Philologica Jassyensia”, XV (2), p. 245-258.

Карпов, А.П. (1877). Азбуковники или алфавиты иностранных речей по спискам Соловецкой библиотеки [Lexicoane și bucoavne ale limbilor străine în manuscrisele biblotecii Solovieț], Tipografia Universității Imperiale, Kazani.

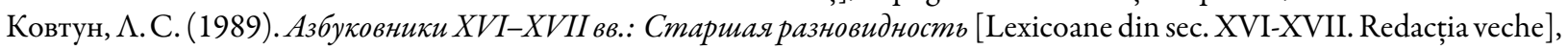
Наука Publishing House, Sankt Petersburg.

Kusmaul', S. (2017). Evolution of the Functions of the Kamora Sign In Liturgical Books from the Late 16th To the First Half of the 17th Centuries, în „St.Tikhons' University Review”, seria III. Philology, 51, p. 21-47.

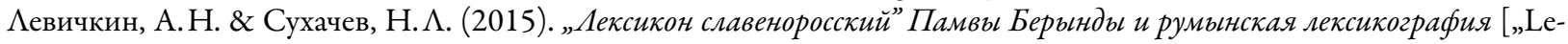
xiconul slavenorus" al lui Pamvo Berînda și lexicografia românească], în Aкадемик A. А. Шахматов: жизнь, творчество, научное наследие. Сборник статей к 150-летию со дня рождения ученого, еd. О. Н. Крылова, М. Н. Приемышев, Sankt Petersburg.

Strungaru, D. (1966). Inceputurile lexicografiei române, în „Romanoslavica”, XIII, p. 141-158.

Strungaru, D. (1973). Staicu Grămăticul. Contribuții la istoria scrisului românesc din secolul al XVII-lea, rezumatul tezei de doctorat, București, Centrul de Multiplicare al Universității din București. 


\section{Sigle}

BAR = Biblioteca Academiei Române

BNR = Biblioteca Națională a Rusiei

RGADA = Arhiva Rusă de Stat a Actelor Vechi 